\title{
Virgibacillus alimentarius sp. nov., isolated from a traditional Korean food
}

\author{
Jandi Kim, ${ }^{1}$ Mi-Ja Jung, ${ }^{1}$ Seong Woon Roh, ${ }^{1}$ Young-Do Nam, ${ }^{1}$ \\ Kee-Sun Shin $^{2}$ and Jin-Woo Bae ${ }^{1}$ \\ ${ }^{1}$ Department of Life and Nanopharmaceutical Sciences and Department of Biology, \\ Kyung Hee University, Seoul 130-701, Republic of Korea \\ ${ }^{2}$ Korea Research Institute of Bioscience and Biotechnology (KRIBB), Daejeon 305-806, \\ Republic of Korea
}

Correspondence

Jin-Woo Bae

baejw@khu.ac.kr

\begin{abstract}
A novel, Gram-positive, rod-shaped, motile, endospore-forming, halophilic bacterial strain, $\mathrm{J}^{1} 8^{\top}$, was isolated from a traditional salt-fermented seafood made of gizzard shad in Korea. Colonies were convex, cream-coloured and 1.0-2.0 mm in diameter after incubation for 3 days on marine

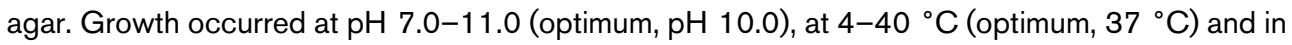
the presence of $0-30 \% \mathrm{NaCl}$ (optimum, 9-10\%). On the basis of 16S rRNA gene sequence analysis, strain $\mathrm{J} 18^{\top}$ was related most closely to Virgibacillus byunsanensis ISL- $24^{\top}(96.3 \%$ similarity), Virgibacillus carmonensis LMG $20964^{\top}$ (96.2\%), Virgibacillus halodenitrificans DSM $10037^{\top}(96.0 \%)$, Virgibacillus arcticus $\mathrm{Hal} 1^{\top}$ (95.5\%) and Virgibacillus necropolis LMG $19488^{\top}$ $(95.5 \%)$. The major fatty acids were anteiso- $C_{15: 0}$ and anteiso- $C_{17: 0}$. The DNA G $+C$ content of strain $\mathrm{J}^{\top} 8^{\top}$ was $37.0 \mathrm{~mol} \%$. The cell-wall peptidoglycan was of the meso-diaminopimelic acid type. The major quinone was menaquinone 7 (MK-7). Based on phenotypic, chemotaxonomic and phylogenetic data, strain $\mathrm{J} 18^{\top}$ is considered to represent a novel species of the genus

Virgibacillus, for which the name Virgibacillus alimentarius sp. nov. is proposed. The type strain is J18 $8^{\top}\left(=\right.$ KACC $\left.14624^{\top}=J C M 16994^{\top}\right)$.
\end{abstract}

The genus Virgibacillus was originally described by Heyndrickx et al. (1998) and, at the time of writing, comprises 21 recognized species: $V$. pantothenticus (Heyndrickx et al., 1998), V. proomii (Heyndrickx et al., 1999), V. marismortui (Arahal et al., 2000), V. carmonensis, $V$. necropolis (Heyrman et al., 2003), V. salexigens (Heyrman et al., 2003), V. halodenitrificans (Yoon et al., 2004), V. dokdonensis (Yoon et al., 2005), V. koreensis (Lee et al., 2006), V. halophilus (An et al., 2007), V. olivae (Quesada et al., 2007), V. chiguensis (Wang et al., 2008), V. kekensis (Chen et al., 2008), V. salarius (Hua et al., 2008), V. arcticus (Niederberger et al., 2009), V. byunsanensis (Yoon et al., 2010), V. salinus (Carrasco et al., 2009), V. sediminis (Chen et al., 2009), V. xinjiangensis (Jeon et al., 2009), V. soli (Kämpfer et al., 2011; Kazimirov et al., 1998) and $V$. subterraneus (Wang et al., 2010). Members of the genus are Gram-positive, motile, flagellated, rod-shaped, endosporeforming halophiles. They have DNA G $+\mathrm{C}$ contents ranging from 33.4 to $42.6 \mathrm{~mol} \%$, their cell-wall peptidoglycan is of the meso-diaminopimelic acid type, except for $V$. arcticus, which has peptidoglycan type $\mathrm{A} 1 \alpha$, and menaquinone 7

The GenBank/EMBL/DDBJ accession number for the 16S rRNA gene sequence of strain $\mathrm{J} 18^{\top}$ is GU202420.

One supplementary figure is available with the online version of this paper.
(MK-7) is the predominant isoprenoid quinone. In this study, we describe a novel strain, $\mathrm{J}_{1}{ }^{\mathrm{T}}$, and show that this represents a novel species of the genus Virgibacillus based on phenotypic and chemotaxonomic characteristics as well as on phylogenetic analysis of $16 \mathrm{~S}$ rRNA gene sequences.

Strain $J 18^{\mathrm{T}}$ was isolated from jeotgal, a traditional saltfermented seafood made by mixing fresh gizzard shad with rock salt and leaving it to ferment (Suh \& Yoon, 1987). Isolation was performed with the dilution-plating method on marine agar (MA; BBL) at $25{ }^{\circ} \mathrm{C}$ and on trypticase soy agar (TSA; BBL) plates. Growth at $\mathrm{pH} 3-12$ was examined by using trypticase soy broth (TSB; BBL). TSB adjusted to $\mathrm{pH} 10.0$ was used to determine $\mathrm{NaCl}$ requirements and tolerance ranges $(0-30 \%)$, and growth at $0,4,10,15,25$, $30,37,40$ and $45^{\circ} \mathrm{C}$. Strain $\mathrm{J}_{1} 8^{\mathrm{T}}$ grew at $\mathrm{pH} 7.0-11.0$, at 4$40{ }^{\circ} \mathrm{C}$ and in the presence of $0-30 \% \mathrm{NaCl}$, with optimal growth occurring at $\mathrm{pH} 10.0$, at $37{ }^{\circ} \mathrm{C}$ and with $9-10 \%$ $\mathrm{NaCl}$. Anaerobic growth was determined following incubation at $37{ }^{\circ} \mathrm{C}$ on TSA in an anaerobic chamber (BACLITE2; Sheldon Manufacturing) with an atmosphere of $\mathrm{N}_{2} / \mathrm{CO}_{2} /$ $\mathrm{H}_{2}$ (18:1:1, by volume). Cell morphology was inspected under a light microscope (model ECLIPSE 50 $i$; Nikon) and a transmission electron microscope (model JEM-1010; JEOL). The Gram reaction was determined by using the $3 \% \mathrm{KOH}$ method (Buck, 1982). Motility was examined 
according to the method of Tittsler \& Sandholzer (1936) with semi-solid agar. Endospore formation was examined with the spore-staining method (Schaeffer \& Fulton, 1933). Catalase and oxidase tests were performed by using $3 \% \quad \mathrm{H}_{2} \mathrm{O}_{2}$ and an oxidase reagent (bioMérieux). Hydrolysis of starch, casein, and Tweens 20, 40, 60 and 80 was determined as described by Smibert \& Kreig (1994). Physiological and biochemical characteristics were determined by using API $20 \mathrm{E}$ and API $50 \mathrm{CH}$ test strips according to the manufacturer's instructions (bioMérieux). The CHB suspension medium for the API $50 \mathrm{CH}$ test strips was supplemented with $7 \% \mathrm{NaCl}$. The API tests were read after $48 \mathrm{~h}$. Colonies were circular, convex, cream-coloured and $1.0-2.0 \mathrm{~mm}$ in diameter after incubation for 3 days on MA. Cells were strictly aerobic, motile, flagellated, endospore-forming, Gram-positive rods, approximately $0.5 \mu \mathrm{m}$ wide and $1.2 \mu \mathrm{m}$ long. Strain $\mathrm{J} 8^{\mathrm{T}}$ was catalase-negative and oxidase-positive. It was positive for hydrolysis of Tweens 20, 40 and 60, but negative for hydrolysis of casein, starch and Tween 80 . A detailed description is presented in the species description below, and Table 1 provides a phenotypic comparison of strain $J 18^{\mathrm{T}}$ and the type strains of four related species of the genus Virgibacillus.
The $16 \mathrm{~S}$ rRNA gene sequence of strain $\mathrm{J} 18^{\mathrm{T}}$ was amplified by PCR by using PCR Pre-mix (Solgent) and two universal primers: forward primer $8 \mathrm{~F}$ ( $5^{\prime}$-AGAGTTTGATCCTGGCTCAG-3') and reverse primer 1492R (5'-GGYTACCTTGTTACGACTT- $3^{\prime}$ ). The PCR product was purified with a QIAquick PCR Purification kit (Qiagen). After purification, the PCR product was sequenced by using the BigDye Terminator Cycle Sequencing Ready Reaction kit (Applied Biosystems) as previously described (Roh et al., 2008). $16 \mathrm{~S}$ rRNA gene sequences were assembled by using the SeqMan software (DNASTAR). Sequence similarities were determined via the EzTaxon server (Chun et al., 2007) to identify the closest phylogenetic neighbours of strain $\mathrm{J} 8^{\mathrm{T}}$. The nearly full-length $16 \mathrm{~S}$ rRNA gene sequence of strain $\mathrm{J} 18^{\mathrm{T}}$ (1458 bp) and reference 16S rRNA gene sequences collected from GenBank were aligned by using the CLUSTAL X multiple sequence alignment program (Thompson et al., 1997). Phylogenetic distances from representative species of the genus Virgibacillus were determined with the MEGA 4 software (Tamura et al., 2007). Phylogenetic trees were generated by using the neighbour-joining (Saitou \& Nei, 1987), minimum-evolution (Rzhetsky \& Nei, 1992) and maximum-parsimony (Kluge \& Farris, 1969) methods. A bootstrap test with 1000 replicates was used to determine the

Table 1. Differential characteristics between strain $J 18^{\top}$ and the type strains of closely related species of the genus Virgibacillus

Strains: 1 , $\mathrm{J}_{1} 8^{\mathrm{T}} ; 2$, V. halodenitrificans DSM $10037^{\mathrm{T}}$ (data from Yoon et al., 2004); 3, V. carmonensis LMG $20964^{\mathrm{T}}$ (Heyrman et al., 2003); 4, V. necropolis LMG $19488^{\mathrm{T}}$ (Heyrman et al., 2003); 5, V. halophilus IAM $15308^{\mathrm{T}}$ (An et al., 2007). W, Weakly positive.

\begin{tabular}{|c|c|c|c|c|c|}
\hline Characteristic & 1 & 2 & 3 & 4 & 5 \\
\hline Pigmentation & Cream & Yellow & Pink & Cream & Yellow \\
\hline Growth temperature $\left({ }^{\circ} \mathrm{C}\right)$ & $4-40$ & $10-45$ & $10-40$ & $10-40$ & $5-45$ \\
\hline Spore shape ${ }^{\star}$ & $\mathrm{E}$ & $\mathrm{E}$ & E or $S$ & $\mathrm{E}$ & E \\
\hline Spore position $\dagger$ & $\mathrm{T}$ or ST & $\mathrm{T}$ or ST & ST & $\mathrm{C}$ or $\mathrm{ST}$ or $\mathrm{T}$ & ST \\
\hline Anaerobic growth & - & + & - & - & - \\
\hline \multicolumn{6}{|l|}{ Acid production from: } \\
\hline Glycerol & + & + & - & $\mathrm{W}$ & - \\
\hline D-Ribose & - & - & - & - & + \\
\hline D-Xylose & - & - & - & - & + \\
\hline D-Galactose & - & + & - & - & - \\
\hline D-Glucose & - & $\mathrm{w}$ & - & - & + \\
\hline D-Fructose & - & + & - & + & + \\
\hline D-Mannose & - & + & - & - & + \\
\hline L-Rhamnose & - & - & - & $\mathrm{w}$ & - \\
\hline$N$-Acetylglucosamine & + & + & $\mathrm{w}$ & $\mathrm{w}$ & + \\
\hline Aesculin & + & - & + & - & + \\
\hline Melibiose & - & - & - & $\mathrm{w}$ & - \\
\hline Sucrose & - & + & - & - & + \\
\hline Trehalose & - & + & - & - & + \\
\hline Potassium 5-ketogluconate & + & + & + & $\mathrm{w}$ & - \\
\hline DNA G $+C$ content $(\mathrm{mol} \%)$ & 37.0 & $38.0-39.0$ & 38.9 & 37.3 & 42.6 \\
\hline
\end{tabular}

${ }^{\star}$ E, ellipsoidal; S, spherical.

$\dagger \mathrm{C}$, central; ST, subterminal; T, terminal. 
confidence of the branching patterns of the trees created (Felsenstein, 1985). Strain J18 ${ }^{\mathrm{T}}$ was most closely related to $V$. byunsanensis ISL-24 ${ }^{\mathrm{T}}(96.3 \%$ 16S rRNA gene sequence similarity), V. carmonensis LMG $20964^{\mathrm{T}}(96.2 \%), \quad$ V. halodenitrificans DSM $10037^{\mathrm{T}}(96.0 \%), V$. arcticus Hal $1^{\mathrm{T}}$ $(95.5 \%)$ and $V$. necropolis LMG $19488^{\mathrm{T}}(95.5 \%)$. These values are all below $97.0 \%$, indicating that strain $\mathrm{J} 8^{\mathrm{T}}$ represents a novel species. The phylogenetic relationships between strain $J 18^{\mathrm{T}}$ and the type strains of recognized species of the genus Virgibacillus are shown in Fig. 1.

Analysis of cellular fatty acids was conducted by using cells grown on MA for 3 days at $37^{\circ} \mathrm{C}$. Cellular fatty acids were extracted, analysed by GC (Hewlett Packard 6890) and identified by using the Sherlock Microbial Identification System (MIDI). The main cellular fatty acids of strain $\mathrm{J} 8^{\mathrm{T}}$ were anteiso- $\mathrm{C}_{15: 0}(52.1 \%)$, anteiso- $\mathrm{C}_{17: 0}(32.0 \%)$, iso- $\mathrm{C}_{16: 0}(4.5 \%)$, iso- $\mathrm{C}_{17: 1}$ and/or anteiso- $\mathrm{C}_{17: 1}(4.0 \%)$, $\mathrm{C}_{16: 0}(3.1 \%)$, iso- $\mathrm{C}_{15: 0}(2.4 \%)$ and $\mathrm{C}_{16: 1} \omega 11 c(2.0 \%)$. The amino acid composition of cell-wall hydrolysates was determined by using one-dimensional TLC on cellulose sheets (Bousfield et al., 1985). The diagnostic amino acid of the cell wall was meso-diaminopimelic acid. The major polar lipids were extracted according to Xin et al. (2000), separated by two-dimensional TLC on a Merck silica gel 60 F254 glassbacked plate with chloroform/methanol/water $(65: 25: 4$, by volume) as the first solvent and chloroform/acetic acid/ methanol/water (80:15:12:4, by volume) as the second solvent, and detected by spraying the plate with specific reagents, as described by Tindall (1990). The designations of all spots were as referred to by Kämpfer et al. (2011). The polar lipids present were diphosphatidylglycerol, phosphatidylglycerol, phosphatidylethanolamine and two unknown lipids (see Supplementary Fig. S1 available in IJSEM Online).

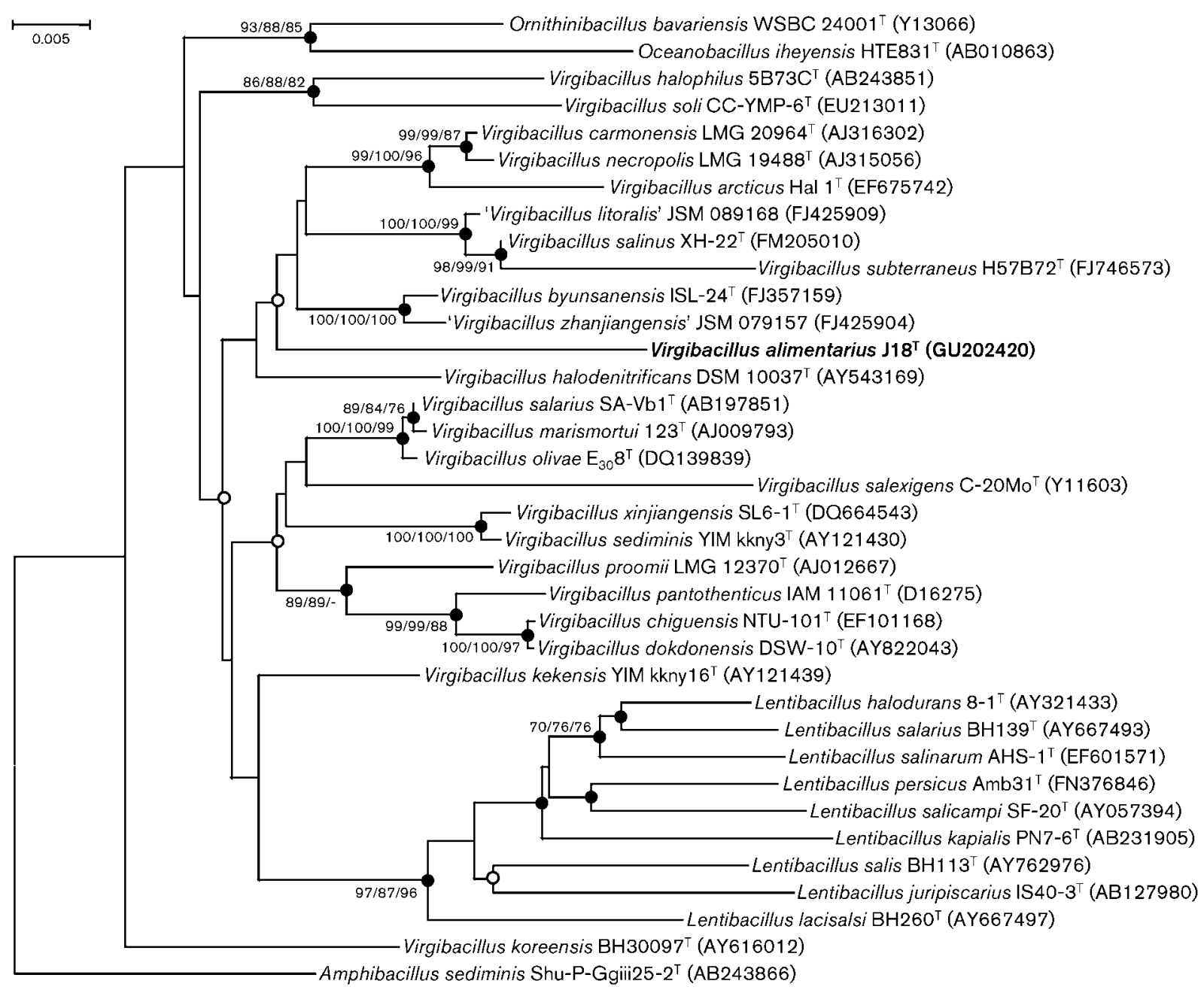

Fig. 1. Neighbour-joining phylogenetic tree based on $16 \mathrm{~S}$ rRNA gene sequences, showing the position of strain $\mathrm{J}^{\mathrm{T}} 8^{\top}$ among related taxa. Filled circles and open circles indicate generic branches that were also recovered by using the minimum-evolution and maximum-parsimony algorithms, and the minimum-evolution algorithm, respectively. Numbers at nodes are bootstrap values (expressed as percentages of 1000 replications) as calculated based on neighbour-joining/minimum-evolution/maximumparsimony probabilities; only values greater than $70 \%$ are shown. Bar, 0.005 accumulated changes per nucleotide. 
Quinone extraction was performed following the method of Komagata \& Suzuki (1987). MK-7 was the predominant menaquinone in strain $\mathrm{J} 18^{\mathrm{T}}$.

Genomic DNA was extracted by using a G-spin DNA extraction kit (iNtRON Biotechnology). The genomic G $+\mathrm{C}$ content was estimated with a fluorimetric method by using SYBR Green I and real-time PCR (Gonzalez \& Saiz-Jimenez, 2002). Genomic DNA from the completely sequenced Bacteroides finegoldii DSM $17565^{\mathrm{T}}$ and Escherichia coli K12 was used for calibration. The DNA G $+\mathrm{C}$ content of strain $\mathrm{J} 18^{\mathrm{T}}$ was $37.0 \mathrm{~mol} \%$. This result is consistent with values reported for recognized members of the genus Virgibacillus, further supporting the affiliation of the isolate to this genus.

Phenotypic (major fatty acid profile, predominant isoprenoid quinone, cell-wall peptidoglycan type) and genotypic characteristics (genomic DNA G + C content) support the inclusion of strain $\mathrm{J}_{1} 8^{\mathrm{T}}$ in the genus Virgibacillus. However, morphological, cultural, physiological and biochemical characteristics, as well as low levels of 16S rRNA gene sequence similarity between strain $J 18^{\mathrm{T}}$ and the type strains of recognized species of the genus Virgibacillus, support its recognition as a representative of a novel species, for which we propose the name Virgibacillus alimentarius sp. nov.

\section{Description of Virgibacillus alimentarius sp. nov.}

Virgibacillus alimentarius (a.li.men.ta'ri.us. L. masc. adj. alimentarius pertaining to food).

Colonies are circular, convex, cream-coloured and 1.0$2.0 \mathrm{~mm}$ in diameter after incubation for 3 days on MA. Cells are aerobic, Gram-positive, motile rods $(0.5 \times 1.2 \mu \mathrm{m})$ which form chains. Oxidase-positive but catalase-negative. Spores are formed in terminal or subterminal position. Growth occurs at $\mathrm{pH}$ 7.0-11.0 (optimum, $\mathrm{pH} 10.0$ ), at 4$40{ }^{\circ} \mathrm{C}$ (optimum, $37{ }^{\circ} \mathrm{C}$ ) and with $0-30 \% \mathrm{NaCl}$ (optimum, 9-10\%). Hydrolyses Tweens 20, 40 and 60. Produces acetoin, but not ONPG, arginine dihydrolase, lysine decarboxylase, ornithine decarboxylase, citrate, hydrogen sulphide, urease, tryptophan deaminase, indole or gelatinase. Acid is produced from glycerol, D-ribose, D-adonitol, D-glucose, $N$-acetylglucosamine, aesculin, D-tagatose, potassium 2-ketogluconate and potassium 5-ketogluconate, but not from erythritol, D-arabinose, L-arabinose, D-xylose, Lxylose, methyl $\beta$-D-xylopyranoside, D-galactose, D-fructose, D-mannose, L-sorbose, L-rhamnose, dulcitol, inositol, Dmannitol, D-sorbitol, methyl $\alpha$-D-mannopyranoside, methyl $\alpha$-D-glucopyranoside, amygdalin, arbutin, salicin, cellobiose, maltose, lactose, melibiose, sucrose, trehalose, inulin, melezitose, raffinose, starch, glycogen, xylitol, turanose, D-lyxose, D-fucose, L-fucose, D-arabitol, L-arabitol or potassium gluconate. The predominant fatty acids are anteiso- $C_{15: 0}$, anteiso- $C_{17: 0}$, iso- $C_{16: 0}$, iso- $C_{17: 1}$ and/or anteiso- $\mathrm{C}_{17: 1}, \mathrm{C}_{16: 0}$, iso- $\mathrm{C}_{15: 0}$ and $\mathrm{C}_{16: 1} \omega 11 \mathrm{c}$. The polar lipids present are diphosphatidylglycerol, phosphatidylglycerol, phosphatidylethanolamine and two unknown lipids. The genomic DNA $\mathrm{G}+\mathrm{C}$ content of the type strain is
$37.0 \mathrm{~mol} \%$. The cell-wall peptidoglycan is of the mesodiaminopimelic acid type. The predominant menaquinone is MK-7.

The type strain, $\mathrm{J} 18^{\mathrm{T}}\left(=\mathrm{KACC} 14624^{\mathrm{T}}=\mathrm{JCM} 16994^{\mathrm{T}}\right)$, was isolated from a traditional salt-fermented seafood made from gizzard shad in Korea.

\section{Acknowledgements}

We thank J. P. Euzéby (Ecole Nationale Vétérinaire, France) for etymological advice. This study was supported by the TDPAF (Technology Development Program for Agriculture and Forestry).

\section{References}

An, S. Y., Asahara, M., Goto, K., Kasai, H. \& Yokota, A. (2007). Virgibacillus halophilus sp. nov., spore-forming bacteria isolated from soil in Japan. Int J Syst Evol Microbiol 57, 1607-1611.

Arahal, D. R., Márquez, M. C., Volcani, B. E., Schleifer, K. H. \& Ventosa, A. (2000). Reclassification of Bacillus marismortui as Salibacillus marismortui comb. nov. Int J Syst Evol Microbiol 50, 1501-1503.

Bousfield, I. J., Keddie, R. M., Dando, T. R. \& Shaw, S. (1985). Simple rapid methods of cell wall analysis as an aid in the identification of aerobic coryneform bacteria. In Chemical Methods in Bacterial Systematics, pp. 221-236. Edited by M. Goodfellow \& D. E. Minnikin. London: Academic Press.

Buck, J. D. (1982). Nonstaining $(\mathrm{KOH})$ method for determination of gram reactions of marine bacteria. Appl Environ Microbiol 44, 992993.

Carrasco, I. J., Márquez, M. C. \& Ventosa, A. (2009). Virgibacillus salinus sp. nov., a moderately halophilic bacterium from sediment of a saline lake. Int J Syst Evol Microbiol 59, 3068-3073.

Chen, Y. G., Cui, X. L., Fritze, D., Chai, L. H., Schumann, P., Wen, M. L., Wang, Y. X., Xu, L. H. \& Jiang, C. L. (2008). Virgibacillus kekensis sp. nov., a moderately halophilic bacterium isolated from a salt lake in China. Int J Syst Evol Microbiol 58, 647-653.

Chen, Y. G., Cui, X. L., Wang, Y. X., Zhang, Y. O., Tang, S. K., Li, W. J., Liu, Z. X., Wen, M. L. \& Peng, Q. (2009). Virgibacillus sediminis sp. nov., a moderately halophilic bacterium isolated from a salt lake in China. Int J Syst Evol Microbiol 59, 2058-2063.

Chun, J., Lee, J. H., Jung, Y., Kim, M., Kim, S., Kim, B. K. \& Lim, Y. W. (2007). EzTaxon: a web-based tool for the identification of prokaryotes based on $16 \mathrm{~S}$ ribosomal RNA gene sequences. Int J Syst Evol Microbiol 57, 2259-2261.

Felsenstein, J. (1985). Confidence limits on phylogenies: an approach using the bootstrap. Evolution 39, 783-791.

Gonzalez, J. M. \& Saiz-Jimenez, C. (2002). A fluorimetric method for the estimation of $\mathrm{G}+\mathrm{C}$ mol\% content in microorganisms by thermal denaturation temperature. Environ Microbiol 4, 770-773.

Heyndrickx, M., Lebbe, L., Kersters, K., De Vos, P., Forsyth, G. \& Logan, N. A. (1998). Virgibacillus: a new genus to accommodate Bacillus pantothenticus (Proom and Knight 1950). Emended description of Virgibacillus pantothenticus. Int J Syst Bacteriol 48, 99-106.

Heyndrickx, M., Lebbe, L., Kersters, K., Hoste, B., De Wachter, R., De Vos, P., Forsyth, G. \& Logan, N. A. (1999). Proposal of Virgibacillus proomii sp. nov. and emended description of Virgibacillus pantothenticus (Proom and Knight 1950) Heyndrickx et al. 1998. Int J Syst Bacteriol 49, 1083-1090. 
Heyrman, J., Logan, N. A., Busse, H.-J., Balcaen, A., Lebbe, L. Rodriguez-Diaz, M., Swings, J. \& De Vos, P. (2003). Virgibacillus carmonensis sp. nov., Virgibacillus necropolis sp. nov. and Virgibacillus picturae sp. nov., three novel species isolated from deteriorated mural paintings, transfer of the species of the genus Salibacillus to Virgibacillus, as Virgibacillus marismortui comb. nov. and Virgibacillus salexigens comb. nov., and emended description of the genus Virgibacillus. Int J Syst Evol Microbiol 53, 501-511.

Hua, N. P., Hamza-Chaffai, A., Vreeland, R. H., Isoda, H. \& Naganuma, T. (2008). Virgibacillus salarius sp. nov., a halophilic bacterium isolated from a Saharan salt lake. Int J Syst Evol Microbiol 58, 2409-2414.

Jeon, C. O., Kim, J. M., Park, D. J., Xu, L. H., Jiang, C. L. \& Kim, C. J. (2009). Virgibacillus xinjiangensis sp. nov., isolated from a Salt Lake of Xin-jiang Province in China. J Microbiol 47, 705-709.

Kämpfer, P., Arun, A. B., Busse, H.-J., Langer, S., Young, C. C., Chen, W. M., Syed, A. A. \& Rekha, P. D. (2011). Virgibacillus soli sp. nov., isolated from mountain soil. Int J Syst Evol Microbiol 61, 275-280.

Kazimirov, V. G., Perlin, D. V., Shcherbakova, E. O., Prokopenko, E. I. \& Nesterenko, I. V. (1998). [Use of plasmapheresis in intensive therapy of acute steroid-resistant rejection reaction in renal transplants]. Anesteziol Reanimatol 6, 62-65 (in Russian).

Kluge, A. G. \& Farris, F. S. (1969). Quantitative phyletics and the evolution of anurans. Syst Zool 18, 1-32.

Komagata, K. \& Suzuki, K. (1987). Lipid and cell-wall analysis in bacterial systematics. Methods Microbiol 19, 161-207.

Lee, J. S., Lim, J. M., Lee, K. C., Lee, J. C., Park, Y. H. \& Kim, C. J. (2006). Virgibacillus koreensis sp. nov., a novel bacterium from a salt field, and transfer of Virgibacillus picturae to the genus Oceanobacillus as Oceanobacillus picturae comb. nov. with emended descriptions. Int J Syst Evol Microbiol 56, 251-257.

Niederberger, T. D., Steven, B., Charvet, S., Barbier, B. \& Whyte, L. G. (2009). Virgibacillus arcticus sp. nov., a moderately halophilic, endospore-forming bacterium from permafrost in the Canadian high Arctic. Int J Syst Evol Microbiol 59, 2219-2225.

Quesada, T., Aguilera, M., Morillo, J. A., Ramos-Cormenzana, A. \& Monteoliva-Sánchez, M. (2007). Virgibacillus olivae sp. nov., isolated from waste wash-water from processing of Spanish-style green olives. Int J Syst Evol Microbiol 57, 906-910.

Roh, S. W., Sung, Y., Nam, Y. D., Chang, H. W., Kim, K. H., Yoon, J. H., Jeon, C. O., Oh, H. M. \& Bae, J. W. (2008). Arthrobacter soli sp. nov., a novel bacterium isolated from wastewater reservoir sediment. J Microbiol 46, 40-44.

Rzhetsky, A. \& Nei, M. (1992). Statistical properties of the ordinary least-squares, generalized least-squares, and minimum-evolution methods of phylogenetic inference. J Mol Evol 35, 367-375.
Saitou, N. \& Nei, M. (1987). The neighbor-joining method: a new method for reconstructing phylogenetic trees. Mol Biol Evol 4, 406425.

Schaeffer, A. B. \& Fulton, M. D. (1933). A simplified method of staining endospores. Science 77, 194.

Smibert, R. M. \& Kreig, N. R. (1994). Phenotypic characterization. In Methods for General and Molecular Bacteriology, pp. 607-654. Edited by P. Gerhardt, R. G. E. Murray, W. A. Wood \& N. R. Krieg. Washington, DC: American Society for Microbiology.

Suh, H. K. \& Yoon, S. S. (1987). A study on the regional characteristics of Korean chotkal. Korean J Dietary Culture 2, 45-54.

Tamura, K., Dudley, J., Nei, M. \& Kumar, S. (2007). MEGA4: molecular evolutionary genetics analysis (MEGA) software version 4.0. Mol Biol Evol 24, 1596-1599.

Thompson, J. D., Gibson, T. J., Plewniak, F., Jeanmougin, F. \& Higgins, D. G. (1997). The CLUSTAL_X windows interface: flexible strategies for multiple sequence alignment aided by quality analysis tools. Nucleic Acids Res 25, 4876-4882.

Tindall, B. J. (1990). Lipid composition of Halobacterium lacusprofundi. FEMS Microbiol Lett 66, 199-202.

Tittsler, R. P. \& Sandholzer, L. A. (1936). The use of semi-solid agar for the detection of bacterial motility. J Bacteriol 31, 575-580.

Wang, C. Y., Chang, C. C., Ng, C. C., Chen, T. W. \& Shyu, Y. T. (2008). Virgibacillus chiguensis sp. nov., a novel halophilic bacterium isolated from Chigu, a previously commercial saltern located in southern Taiwan. Int J Syst Evol Microbiol 58, 341-345.

Wang, X. W., Xue, Y. F. \& Ma, Y. H. (2010). Virgibacillus subterraneus sp. nov., a moderately halophilic Gram-positive bacterium isolated from subsurface saline soil. Int J Syst Evol Microbiol 60, 2763-2767.

Xin, H., Itoh, T., Zhou, P., Suzuki, K. I., Kamekura, M. \& Nakase, T. (2000). Natrinema versiforme sp. nov., an extremely halophilic archaeon from Aibi salt lake, Xinjiang, China. Int J Syst Evol Microbiol 50, 1297-1303.

Yoon, J. H., Oh, T. K. \& Park, Y. H. (2004). Transfer of Bacillus halodenitrificans Denariaz et al. 1989 to the genus Virgibacillus as Virgibacillus halodenitrificans comb. nov. Int J Syst Evol Microbiol 54, 2163-2167.

Yoon, J. H., Kang, S. J., Lee, S. Y., Lee, M. H. \& Oh, T. K. (2005). Virgibacillus dokdonensis sp. nov., isolated from a Korean island, Dokdo, located at the edge of the East Sea in Korea. Int J Syst Evol Microbiol 55, 1833-1837.

Yoon, J. H., Kang, S. J., Jung, Y. T., Lee, K. C., Oh, H. W. \& Oh, T. K. (2010). Virgibacillus byunsanensis sp. nov., isolated from a marine solar saltern. Int J Syst Evol Microbiol 60, 291-295. 